\title{
Ethiopian Agriculture: A Dynamic Geographic Perspective
}

\author{
Jordan Chamberlin and Emily Schmidt
}

Development Strategy and Governance Division, International Food Policy Research Institute - Ethiopia Strategy Support Program II, Ethiopia

Ethiopia Strategy Support Program II (ESSP II)

ESSP II Working Paper No. 017

March 2011

IFPRI-ADDIS ABABA

P.O. Box 5689

Addis Ababa, Ethiopia

Tel: +251-11-646-2921

Fax: +251-11-646-2318

E-mail: ifpri-addis@cgiar.org
IFPRI HEADQUARTERS

International Food Policy Research Institute

2033 K Street, NW • Washington, DC 20006-1002

USA

Tel: +1-202-862-5600

Skype: IFPRIhomeoffice

Fax: +1-202-467-4439

E-mail: ifpri@cgiar.org

www.ifpri.org 


\title{
THE ETHIOPIA STRATEGY SUPPORT PROGRAM II (ESSP II) WORKING PAPERS
}

\author{
ABOUT ESSP II \\ The Ethiopia Strategy Support Program II is an initiative to strengthen evidence-based policymaking \\ in Ethiopia in the areas of rural and agricultural development. Facilitated by the International Food \\ Policy Research Institute (IFPRI), ESSP II works closely with the government of Ethiopia, the \\ Ethiopian Development Research Institute (EDRI), and other development partners to provide \\ information relevant for the design and implementation of Ethiopia's agricultural and rural \\ development strategies. For more information, see http://www.ifpri.org/book- \\ 757/ourwork/program/ethiopia-strategy-support-program or http://www.edri.org.et/.
}

\section{ABOUT THESE WORKING PAPERS}

The Ethiopia Strategy Support Program II (ESSP II) Working Papers contain preliminary material and research results from IFPRI and/or its partners in Ethiopia. The papers are not subject to a formal peer review. They are circulated in order to stimulate discussion and critical comment. The opinions are those of the authors and do not necessarily reflect those of their home institutions or supporting organizations.

\footnotetext{
About the Author(s)

Jordan Chamberlin: PhD Candidate, Michigan State University

Emily Schmidt: Country Program Coordinator \& GIS Specialist, International Food Policy Research Institute
} 


\title{
Ethiopian Agriculture: A Dynamic Geographic Perspective
}

\author{
Jordan Chamberlin and Emily Schmidt
}

Development Strategy and Governance Division, International Food Policy Research

Institute - Ethiopia Strategy Support Program 2, Ethiopia

Copyright $\odot 2010$ International Food Policy Research Institute. All rights reserved. Sections of this material may be reproduced for personal and notfor-profit use without the express written permission of but with acknowledgment to IFPRI. To reproduce the material contained herein for profit or commercial use requires express written permission. To obtain permission, contact the Communications Division at ifpri-copyright@cgiar.org. 


\section{Table of Contents}

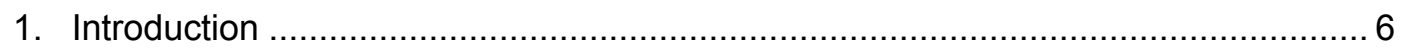

2. Characterizing production contexts .............................................................. 7

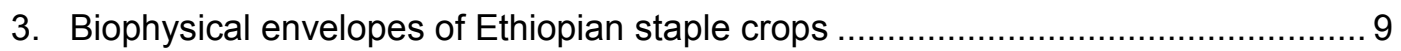

4. Agroecologies and farming systems ..................................................... 11

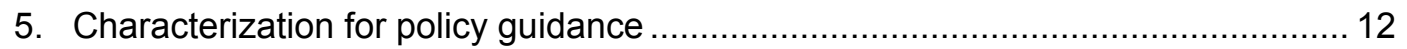

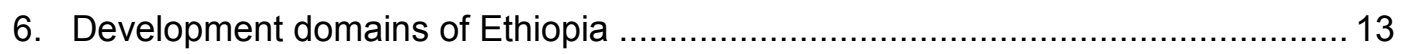

7. Ethiopia's changing economic and biophysical landscape ............................... 17

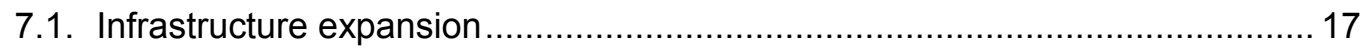

7.2. Improving market access through improved transportation infrastructure ....... 17

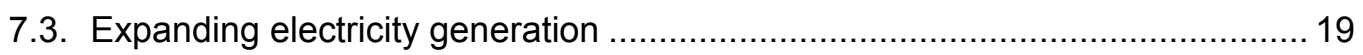

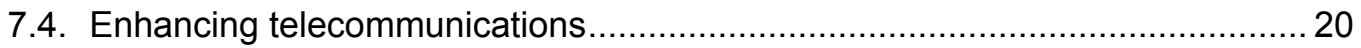

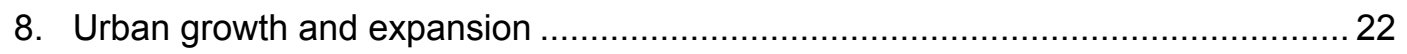

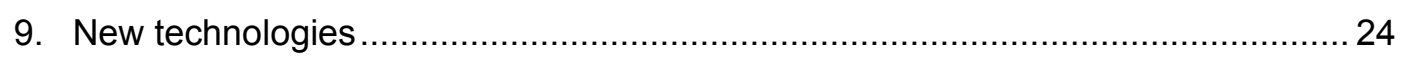

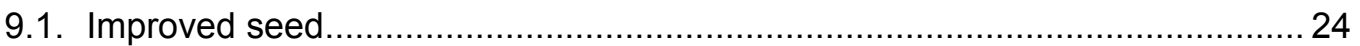

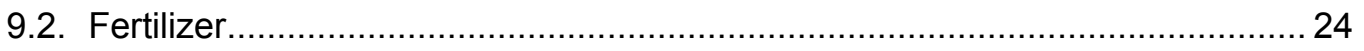

9.3. Spatial variations in technology use …...................................................... 24

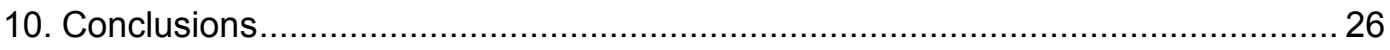

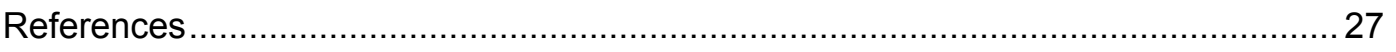




\section{List of Tables}

Table 2.1. Traditional ecological zones and selected crop altitudinal ranges ............... 8

Table 6.1. Domain summary statistics: share of national totals (\%) by domain factor. 14

Table 6.2. Domain summary statistics: domain share of national totals (\%)................ 14

Table 7.1. Percent population connected to a city of at least 50,000 people in 2007 .. 18

Table 7.2. Percent change connected to a city of at least 50,000 people from 1994 to 2007 19

Table 7.3. Electricity generation capacity 1958 to $2011^{*}$ in Ethiopia .......................... 20

Table 7.4. Fixed line and cellular telephones 2003 to 2010 in Ethiopia ....................... 21

Table 8.1. Agglomeration index ${ }^{*}$ Percent of people considered urban by region ..... 22

Table 8.2. Ethiopia: Alternative urbanization estimates ............................................. 23

Table 9.1. Area, production and yields of cereals using modern inputs or traditional technology

\section{List of Figures}

Figure 2.1. Characteristics of rainfall and altitude ...........................................

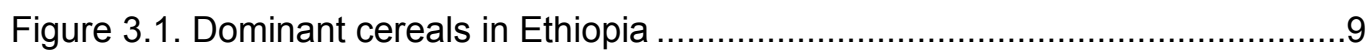

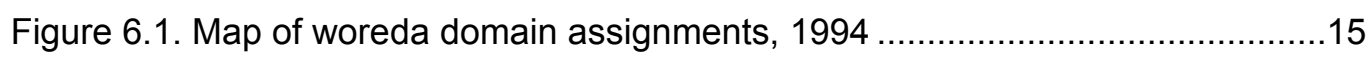

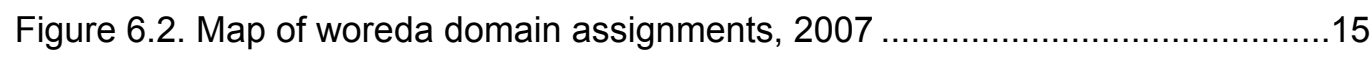

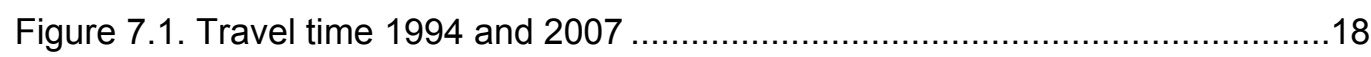

Figure 7.2. Fixed line and cellular telephones 2003 to 2010 in Ethiopia..................21 


\section{Introduction}

The opportunities and constraints facing Ethiopian agriculture are strongly influenced by conditions which vary across geographical space. These conditions include basic agricultural production potentials, access to input and output markets, and local population densities which represent both labor availability and local demand for food. Understanding the geographical expression of these factors is an important way of making sense of Ethiopia's agricultural and rural development options and for guiding the definition of supporting policies.

These conditions not only vary over space, but change over time as well. New and improved roads, expanding telecommunications, improved access to electricity, as well as urban growth, continue to lower transaction costs and improve market access. Changing production opportunities and new technologies have allowed greater flexibility of livelihood decisions within defined biophysical endowments. As Ethiopia continues to invest in infrastructure and technology, the agricultural landscape continues to be reshaped and redefined into broader areas of opportunity and growth.

The objectives of this chapter are twofold. First, we provide an overview of the geographical production contexts that constitute a basic reference for understanding production systems and geography of agricultural production in rural Ethiopia. This characterization is organized around the economic logic of comparative advantage for a variety of generalized production decisions of relevance in Ethiopia. Second, we extend this framework to organize evidence for, and discussion of, important areas of dynamism in Ethiopia's rural economic landscape. Thus, this chapter is mainly a descriptive assessment of important production contexts and the manner in which these contexts are evolving. 


\section{Characterizing production contexts}

In large and heterogeneous countries, such as Ethiopia, agricultural potential is unevenly distributed over space, and the distribution of production patterns reflects this landscape. Mapped zones of smallholder production systems have long been recognized as important in Ethiopia precisely because of such landscape heterogeneity (for example Westphal 1975, Hurni 1998, De Pauw and Bruggeman 1988). To provide a useful characterization of agricultural landscapes, geographical perspectives seek a balance between too little information and too much. On the one hand, spatial characterization is motivated by the fact that average national statistics and one-size-fits-all development strategies are insufficient for effective rural planning. On the other hand, a surfeit of detail may render mapped classifications useless for planning on the basis of shared conditions: hundreds of subcategories, whether in a map or a table, even when they accurately portray local variation, and almost always contain too much information to be tractable as a planning aid. Thus, characterizations generally seek to reduce complexity by prioritizing characteristics which are most meaningful to the production systems of interest.

Agroecological zones are perhaps the predominant methodology used to organize geographic space to understand actual and potential agricultural production.

Agroecological zonation utilizes biophysical attributes of soil, terrain, and climate to organize land-use types or production systems into relatively homogenous units (FAO 1978, Hurni 1998). Hurni (1998) implemented a set of agroecological zone definitions for Ethiopia, based on traditional zone designations widely used by rural residents. He linked these designations with specific elevation and rainfall parameters, which allowed mappable boundaries to be imposed on agroecological zones (Figure 2.1).

Fiqure 2.1. Characteristics of rainfall and altitude

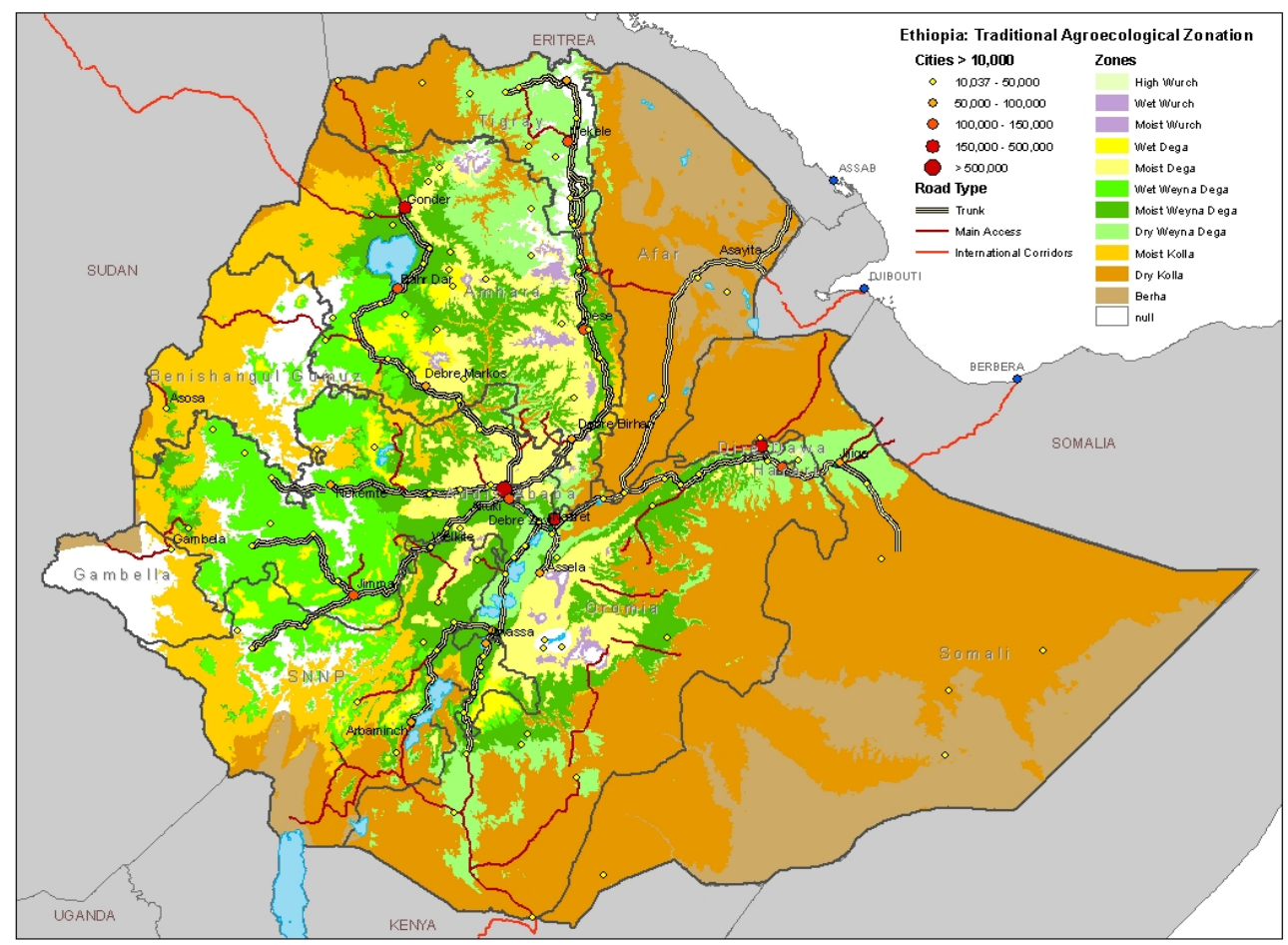

Note: Agroecological zones depicted here are according to Hurni (1998) characterization 
In Ethiopia, most agricultural production takes place in the Dega and Weyna Dega zones, where land productivity has traditionally coincided with the densest rural populations. Figure 2.1 shows these zones in green and yellow, scattered throughout the highlands. Specific crops and livelihood choices within and outside this band are conditioned by moisture and temperature regimes, among other factors. The crops most suited to grow in the Dega and Weyna Dega zones in Ethiopia are also the most commonly produced crops in Ethiopia. Most producers in these zones are smallholders, occupying on average less than a hectare of land per household. ${ }^{1}$ Smallholder production is dominated by five major cereal crops accounting for almost three-quarters of the total cultivated area, and about 68 percent of total production. Each of the major cereals - teff, maize, wheat, sorghum, and barley-has its own distribution, defined primarily by bioclimatic ranges (Table 2.1).

Table 2.1. Traditional ecological zones and selected crop altitudinal ranges

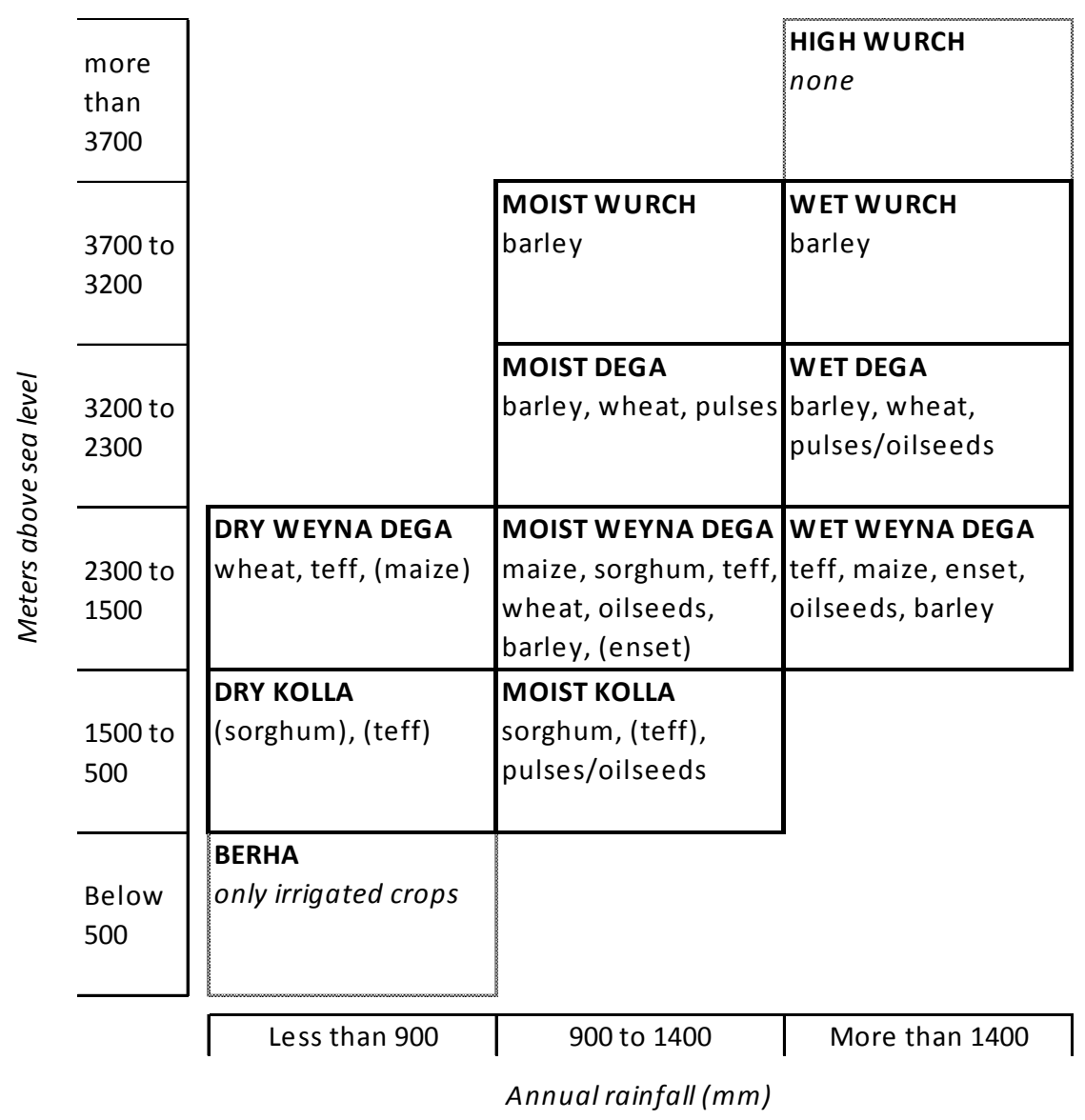

Source: Hurni (1998).

Note: Crops in parentheses have restricted distribution within the zone and/or grow under less than ideal conditions in these areas.

\footnotetext{
${ }^{1}$ Information in this section, unless otherwise cited, is from the Atlas of the Ethiopian Rural Economy (CSA, IFPRI \& EDRI 2006), whose agricultural data are drawn primarily from the 2001/02 Ethiopian Agricultural Sample Enumeration.
} 


\section{Biophysical envelopes of Ethiopian staple crops}

Rural livelihoods are strongly conditioned by the environments in which they are pursued. Ethiopia's agricultural production is characterized and determined by smallholder, rain-fed agriculture practices. Thus, a variety of crops are produced throughout the country in different locations where specific biophysical conditions define the success of production yields and welfare outcomes (Figure 3.1). These locations are dynamic, however. Where rainfall is insufficient in amount or distribution over continuous growing seasons, crop production may cease to be a viable livelihood option. Other non-biophysical factors, such as access to markets, labor availability, local demand (and markets) for food, and export linkages may impose additional limitations on locally viable production options. Here, we briefly explore some of the major crops-cereals, tubers, and pulses-that make up the Ethiopian agricultural economy, emphasizing the conditions under which they are produced.

Figure 3.1. Dominant cereals in Ethiopia

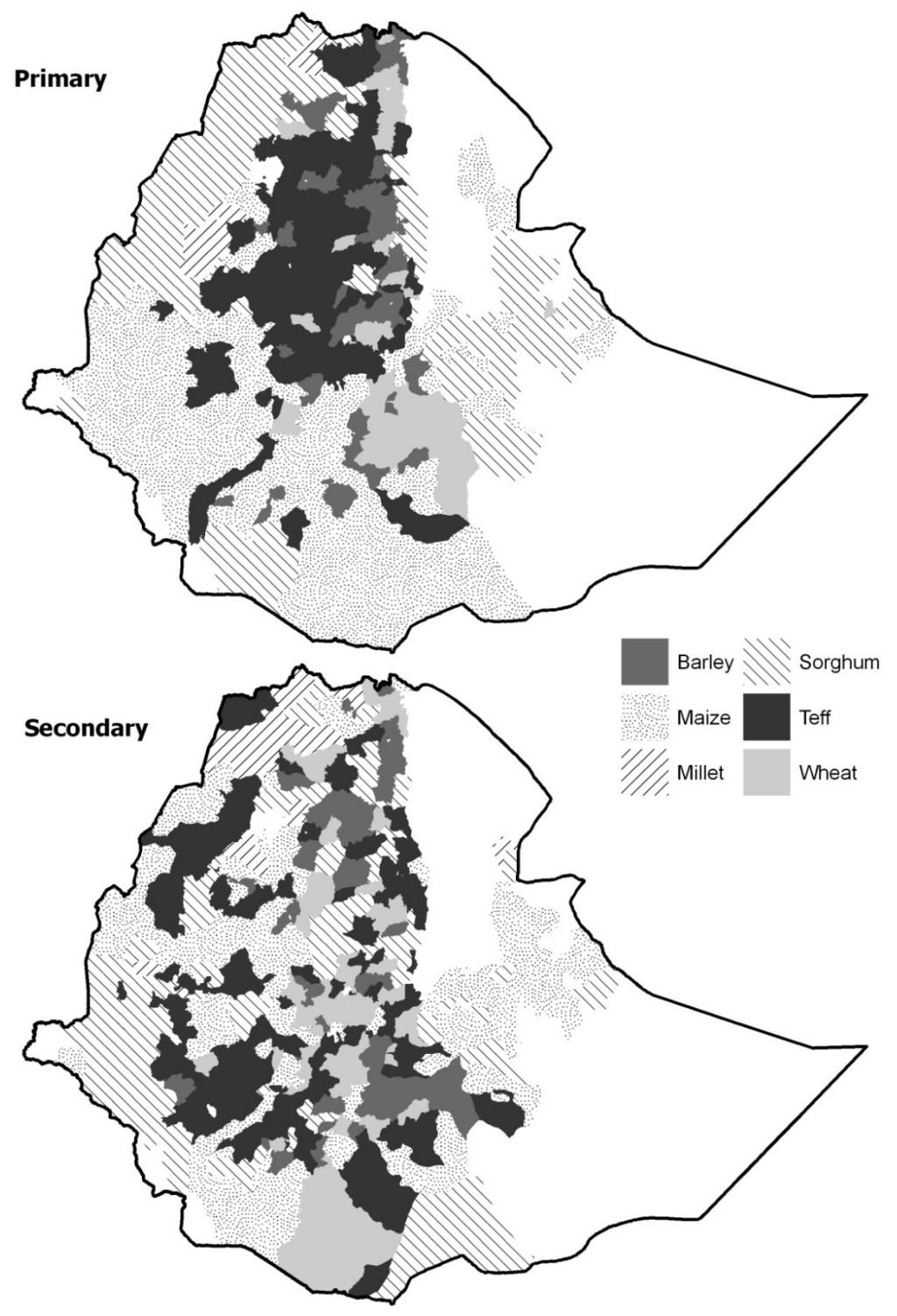

Source: Ethiopian Agricultural Sample Enumeration 2001/02 
Teff (Eragrostis tef) is the preferred staple food in much of the highlands. Teff is grown by nearly half of all farming households (more, if only the highlands are considered) and accounts for 28 percent of all cultivated land, more than any other single crop. Although traditionally grown in the highlands, teff can be grown under a wide variety of agroclimatic conditions, including elevations from zero to 2,800 meters above sea level (masl), under a similarly wide variety of moisture, temperature, and soil conditions. Its optimal growing conditions coincide with its traditional production areas: $1,800-2,100$ masl, average annual rainfall of $750-1,000$ millimeters $(\mathrm{mm})$, and average annual temperature of $10-27^{\circ} \mathrm{C}$.

Maize is the second most widely cultivated cereal in Ethiopia in terms of area, but is produced by more farms than any other crop, accounts for the largest share of production by volume at 18.8 percent, and appears to be increasing. In addition to food grain, maize residues are also used as fodder, fencing materials, and cooking fuel.

Although maize is becoming more widely grown throughout Ethiopia, it is less tolerant of cold than teff, barley, and wheat. While teff can grow at elevations up to 2,800 masl, limited maize production occurs above 2,400 meters. It also has a shallow root system, making moisture availability in upper soil strata important. In Ethiopia, the highest maize yields require an annual rainfall of $800-1,500 \mathrm{~mm}$. More than 60 percent of maize production comes from the Oromia region, followed by Amhara with about 20 percent of total production.

Sorghum accounts for about 17 percent of all area planted with cereals and for about 18 percent of production. Relative to other cereals, sorghum generally has good tolerance for drought and is also tolerant of excess water conditions. These characteristics give sorghum a large range of feasible climate regimes, although it does best in semi-arid conditions, especially relative to other cereals. For example, sorghum can produce grain in areas too dry for maize ( $<250 \mathrm{~mm}$ average annual rainfall). However, it is sensitive to cold temperatures and is rarely found at higher altitudes (2,500 masl may be considered a ceiling).

Wheat accounts for similar shares of national cereal production as sorghum with 17 percent of planted area and 19 percent of production. Varieties include Durum, Emmer, and so-called bread wheat. Durum wheat is often grown for domestic pasta fabrication. Emmer (aja in Amharic) is grown mainly in eastern Oromia (Arsi and Bale) and Amhara (Shewa and Wollo). Bread wheat is widely grown throughout the highlands and transitional areas. Ethiopian wheat production typically takes place at altitudes of 1,600-3,200 masl, in areas with average annual rainfall of $400-1,200 \mathrm{~mm}$ and average annual temperatures of $15-25^{\circ} \mathrm{C}$.

Whereas the highest cereal yields are experienced at lower elevations (between 500 and 2,300 masl), barley production generally increases in importance with altitude. At elevations above 2,500 masl it is frequently the only cereal grown. Nationally, barley is grown by about a third of all cereal producers and occupies about 9 percent of cultivated land. There are many local varieties of barley produced in Ethiopia, with a range of production and consumption characteristics such as rate of maturation and size of grain. Ethiopian barley varieties are reported to be relatively quick-growing and more drought tolerant than other varieties (NRC 1996).

In addition to the major five cereals grown in Ethiopia, enset (Ensete ventricosum, sometimes referred to as false banana) is an important staple in large parts of the southern highlands, where it has been estimated that more than 10 million people depend on enset for food, fiber, and other uses (Brandt et al. 1997). Enset, which is 
cultivated solely in Ethiopia, is planted at elevations ranging from 1,100 to 3,100 masl, although its optimal range is 2,000-2,750 masl. Enset does not tolerate frost and it is not drought resistant. Thus, optimal growing environments are humid and temperate. Annual rainfall in enset growing areas ranges from 1,100-1,500 masl, with average annual temperatures of $10-21^{\circ} \mathrm{C}$.

\section{Agroecologies and farming systems}

Farming systems, encompassing bundled sets of agricultural livelihood choices, including crop type and production technologies, are related to agroecological space in several fundamental ways: production choices must be viable given available technology and physical parameters required for plant growth. To the extent that the latter are reflected in agroecological zones, the spatial expression of traditional farming systems in Ethiopia is at least partially coincident with agroecological zone maps.

Westphal (1975) identified four major farming systems for Ethiopia: seed-farming, enset-planting, shifting cultivation, and pastoral complexes. The seed-farming complex focuses on grain production, particularly cereals, but also pulses and oilseeds. Grain-based, seed-farming production systems are found throughout the central, northern, and eastern highlands and involve the majority of Ethiopian small farmers. Crop choice within the grain-based systems varies widely, as these systems are found from kola (500 masl) to wurch (3,200 masl) altitudinal bands, in moisture conditions ranging from dry to wet. Similarly, the enset-planting complex (grown in moist and wet dega and weyna dega) allows for flexibility of production whereby enset could be the principal staple, a co-staple with cereals and/or tubers, or a minor component of cereal or tuber-based systems. Finally, shifting cultivation and pastoral complexes are most common in the western and eastern lowlands, respectively. In the humid western lowlands (primarily moist kola), disease is a limiting factor for livestock. The arid and semi-arid lowlands in the eastern part of the country (mostly bereha), lack available moisture which limits rain-fed crop production. In both areas, population densities are low, reflecting the low carrying capacities of land resources under current technologies. 


\section{Characterization for policy guidance}

The classification systems described above are roughly contoured. They may easily be (and frequently are) further refined on the basis of more detailed environmental data such as soil type, seasonality, terrain, technology specificity, or local production idiosyncrasies. For example, the Ethiopian Institute of Agricultural Research (EARO) ${ }^{2}$ organizes its research strategies around crops and management issues organized by 18 major and 49 minor agroecological zones ${ }^{3}$, which are refined from the traditional agroclimatic zones outlined above ${ }^{4}$.

For policy guidance, however, more detail may not be what is most required for identifying overarching challenges to the agricultural sector and corresponding investment priorities. Emphasizing the importance of moisture availability for the country's rain-fed production systems, the government of Ethiopia has long framed basic agricultural policy discussions within "Three Ethiopias": moisture reliable highlands, drought prone highlands, and pastoral lowland areas. ${ }^{5}$ For many rural experts, these basic regimes of moisture availability and the production systems therein are the critical distinction when evaluating first-order strategic options for rural development across the country.

However, production choices are not just a function of biophysical endowments, but also socio-economic conditions and the built environment. This includes the local availability of labor, demand for food, cost of transportation between farms, and presence of input and output markets. Development domains are an attempt to build onto agricultural potential by evaluating and organizing economic information within a framework of potential production choices.

\footnotetext{
${ }^{2}$ EIAR was called the Ethiopian Agricultural Research Organization (EARO) until 2006.

${ }^{3} \mathrm{FAO}$ was involved in identifying 18 major and 42 minor agroecological zones in the late 1980's and EIAR has now subdivided some of these zones with a total of 49 currently.

${ }^{4}$ These agroecological zones were developed under an FAO-led project within the Ministry of Agriculture, described by de Pauw (1987).

${ }^{5}$ This characterization has recently been expanded to " 5 Ethiopia's" (drought prone, humid lowland moisture reliable, moisture reliable - cereals, moisture reliable - enset, and pastoralist) for the Ethiopian Social Accounting Matrix developed by the Ethiopian Development Research Institute (EDRI).
} 


\section{Development domains of Ethiopia}

Development domains were developed out of work by Pender, Wood, and colleagues, based on household- and community-level research in Uganda, Ethiopia, and Honduras (Pender et al. 1999; Wood et al. 1999; Pender et al. 2001a, b, c; Nkonya et al. 2004; Pender et al. 2004; Pender 2004 a,b; Pender et al. 2006 a,b). Drawing upon the theory of comparative advantage and location theory (von Thunen 1826; Chomitz and Gray 1996) and the literature on the evolution of farming systems in tropical agriculture (Boserup 1965; Ruthenberg 1980; Pingali et al. 1987; Binswanger and McIntire 1987; McIntire et al. 1992), key components of an area's agricultural development endowment can be understood in terms of a relatively reduced set of conditioning factors: agricultural potential, access to markets, and population density.

Agricultural potential represents the absolute advantage for agricultural livelihoods in that location. Access to markets and population density translate absolute production advantages into comparative advantages (relative profitability) of particular livelihoods. For example, an area with high and reliable rainfall and good soils may have an absolute advantage in producing high-value perishable vegetables, but may have little comparative advantage in this livelihood if it is remote from markets. Population density, by affecting local land-labor ratios, influences the comparative advantage of labor intensive livelihoods. High land-labor ratios in areas with poor access to markets and low agricultural potential endowments may encourage laborintensive but low-external input production strategies. All three factors together influence the profitability of different commodities, production technologies, and land management practices.

Implementing development domains means applying this conceptual framework to identify mappable conditions that broadly enable or constrain development options of national importance. This implies two decisions. First, the scale of strategic planning must be determined. For national strategy formulation, sector-wide perspectives require some level of generalization greater than that typically used in commodity- or technology-specific recommendation domains. A second decision is how best to represent these factors, given local conditions and the relevant scope of perspective. In practice, this means identifying the best indicators to represent relative levels of agricultural endowments for rain fed (and irrigated) agriculture, access to market opportunities, and the availability of labor relative to land.

In Ethiopia, Chamberlin et al. (2006) defined development domains by starting with the long-standing moisture regime distinctions featured in policy discussion of the "Three Ethiopias," and further distinguishing between highland and lowland areas of rain fed agriculture. This yielded a total of five basic zones of agricultural potential (moisture sufficient highlands, moisture sufficient lowlands, drought prone highlands, drought prone lowlands, and pastoralist areas). Socio-economic characteristics were also included in the characterization: two classes of market access (low and high) and three classes of population density (high, medium, and low). The resulting 25 domains were significant predictors of a range of rural livelihood variables at the woreda (district) level.

These domains highlight important aspects of the Ethiopian rural context. Of particular note is the predominance of low access conditions. In 1994, 92 percent of land resources and 69 percent of rural populations were located in low access areas, as defined here (Tables 2 and 3, Figures 3 and 4). These conditions have improved considerably, reducing to 79 percent of land and 40 percent of population in 2007, and represent one of the dimensions of greatest change in Ethiopia over the past two 
decades. ${ }^{6}$ Nonetheless, the portion of the country's land and population resources which may be fairly characterized as remote is still very high. Although high density areas are becoming even denser (and are accounting for larger shares of total populations), almost half of Ethiopia's land and people still reside in low and medium density areas. Many of these areas are also characterized by poor market access.

Table 6.1. Domain summary statistics: share of national totals (\%) by domain factor

\begin{tabular}{|c|c|c|c|c|}
\hline \multirow{2}{*}{ Domain factor } & \multicolumn{2}{|c|}{1994} & \multicolumn{2}{|c|}{2007} \\
\hline & $\%$ area & $\%$ pop & $\%$ area & $\%$ pop \\
\hline \multicolumn{5}{|l|}{ Agricultural potential } \\
\hline Moisture Reliable Highlands & $25 \%$ & $62 \%$ & $31 \%$ & $67 \%$ \\
\hline Moisture Reliable Lowlands & $12 \%$ & $7 \%$ & $9 \%$ & $4 \%$ \\
\hline Drought Prone Highlands & $10 \%$ & $18 \%$ & $9 \%$ & $17 \%$ \\
\hline Drought Prone Lowlands & $16 \%$ & $5 \%$ & $21 \%$ & $6 \%$ \\
\hline Pastoralist & $37 \%$ & $9 \%$ & $30 \%$ & $6 \%$ \\
\hline \multicolumn{5}{|l|}{ Market access } \\
\hline High & $8 \%$ & $31 \%$ & $21 \%$ & $60 \%$ \\
\hline Low & $92 \%$ & $69 \%$ & $79 \%$ & $40 \%$ \\
\hline \multicolumn{5}{|l|}{ Population density } \\
\hline High & $6 \%$ & $32 \%$ & $11 \%$ & $47 \%$ \\
\hline Low \& Medium & $94 \%$ & $68 \%$ & $89 \%$ & $53 \%$ \\
\hline
\end{tabular}

Table 6.2. Domain summary statistics: domain share of national totals (\%)

\begin{tabular}{|c|c|c|c|c|}
\hline \multirow{2}{*}{ Development Domain } & \multicolumn{2}{|c|}{1994} & \multicolumn{2}{|c|}{2007} \\
\hline & $\%$ area & $\%$ pop & $\%$ area & $\%$ pop \\
\hline Moisture Reliable Highlands, High Access, High Density & $8.7 \%$ & $38.6 \%$ & $2.8 \%$ & $18.2 \%$ \\
\hline Moisture Reliable Highlands, High Access, Low Density & $6.3 \%$ & $10.9 \%$ & $2.7 \%$ & $6.5 \%$ \\
\hline Moisture Reliable Highlands, Low Access, High Density & $1.1 \%$ & $3.6 \%$ & $2.1 \%$ & $10.4 \%$ \\
\hline Moisture Reliable Highlands, Low Access, Low Density & $15.2 \%$ & $13.9 \%$ & $17.1 \%$ & $27.4 \%$ \\
\hline Moisture Reliable Lowlands, High Access, High Density & $0.1 \%$ & $0.3 \%$ & $0.0 \%$ & $0.4 \%$ \\
\hline Moisture Reliable Lowlands, High Access, Low Density & $0.2 \%$ & $0.3 \%$ & $0.1 \%$ & $0.2 \%$ \\
\hline Moisture Reliable Lowlands, Low Access, High Density & $0.0 \%$ & $0.0 \%$ & $0.1 \%$ & $0.5 \%$ \\
\hline Moisture Reliable Lowlands, Low Access, Low Density & $8.7 \%$ & $3.7 \%$ & $11.5 \%$ & $5.6 \%$ \\
\hline Drought Prone Highlands, High Access, High Density & $0.8 \%$ & $3.2 \%$ & $0.4 \%$ & $1.9 \%$ \\
\hline Drought Prone Highlands, High Access, Low Density & $3.1 \%$ & $5.1 \%$ & $1.3 \%$ & $2.5 \%$ \\
\hline Drought Prone Highlands, Low Access, High Density & $0.3 \%$ & $1.0 \%$ & $0.3 \%$ & $1.1 \%$ \\
\hline Drought Prone Highlands, Low Access, Low Density & $5.2 \%$ & $7.3 \%$ & $7.5 \%$ & $12.3 \%$ \\
\hline Drought Prone Lowlands, High Access, High Density & $0.1 \%$ & $0.3 \%$ & $0.0 \%$ & $0.0 \%$ \\
\hline Drought Prone Lowlands, High Access, Low Density & $1.2 \%$ & $1.2 \%$ & $0.3 \%$ & $0.6 \%$ \\
\hline Drought Prone Lowlands, Low Access, Low Density & $19.4 \%$ & $5.1 \%$ & $16.1 \%$ & $4.0 \%$ \\
\hline Pastoralist, High Access, Low Density & $0.4 \%$ & $0.3 \%$ & $0.3 \%$ & $0.4 \%$ \\
\hline Pastoralist, Low Access, High Density & $0.0 \%$ & $0.0 \%$ & $0.0 \%$ & $0.0 \%$ \\
\hline \multirow[t]{2}{*}{ Pastoralist, Low Access, Low Density } & $29.3 \%$ & $5.2 \%$ & $37.2 \%$ & $8.2 \%$ \\
\hline & $100 \%$ & $100 \%$ & $100 \%$ & $100 \%$ \\
\hline
\end{tabular}

\footnotetext{
${ }^{6}$ Because the domain classification was made on the basis of woreda boundaries, we acknowledge that some shifts in categories may simply be artifacts of these changing boundaries. Because of this possibility, called the modifiable areal unit problem (Openshaw 1984), we restrict our discussion to broad changes in characteristics, rather than shifts between individual domains, especially those which restricted distributions and which may be less robust.
} 
Figure 6.1. Map of woreda domain assignments, 1994
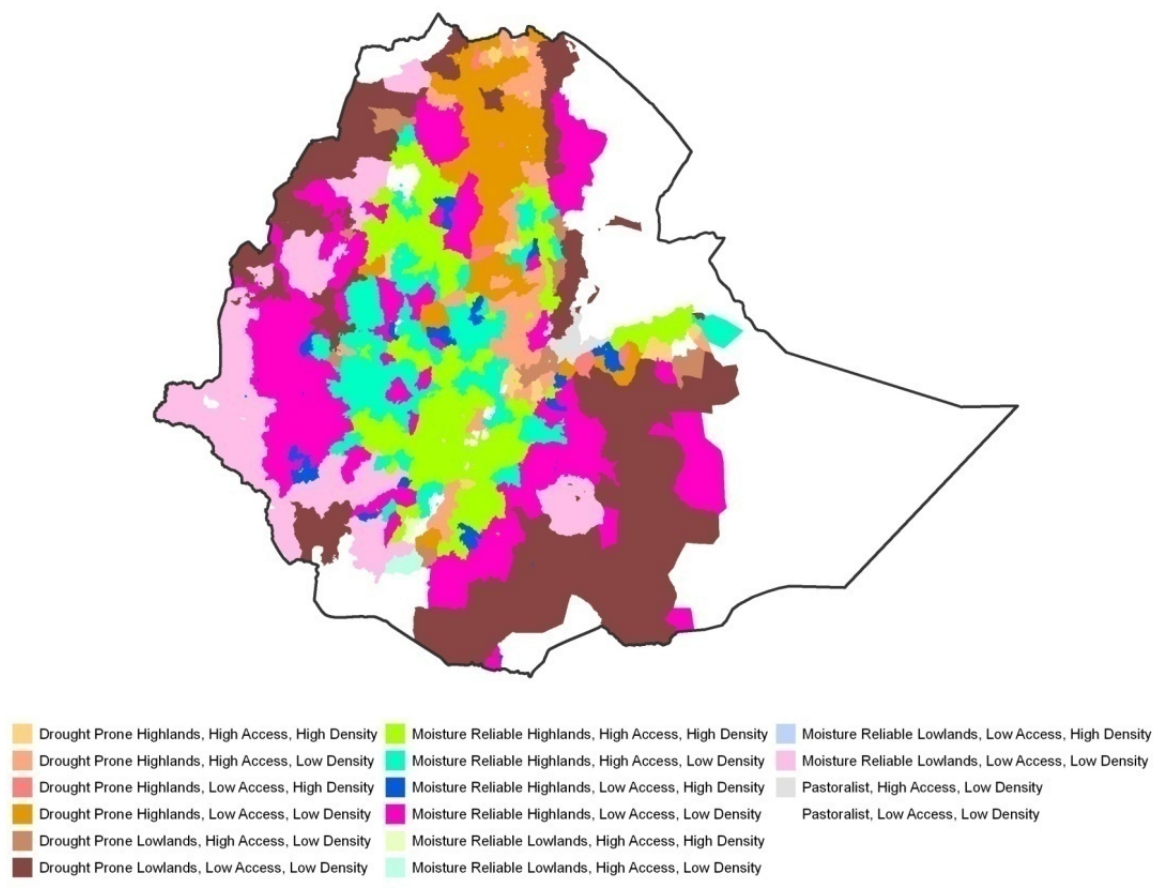

Figure 6.2. Map of woreda domain assignments, 2007

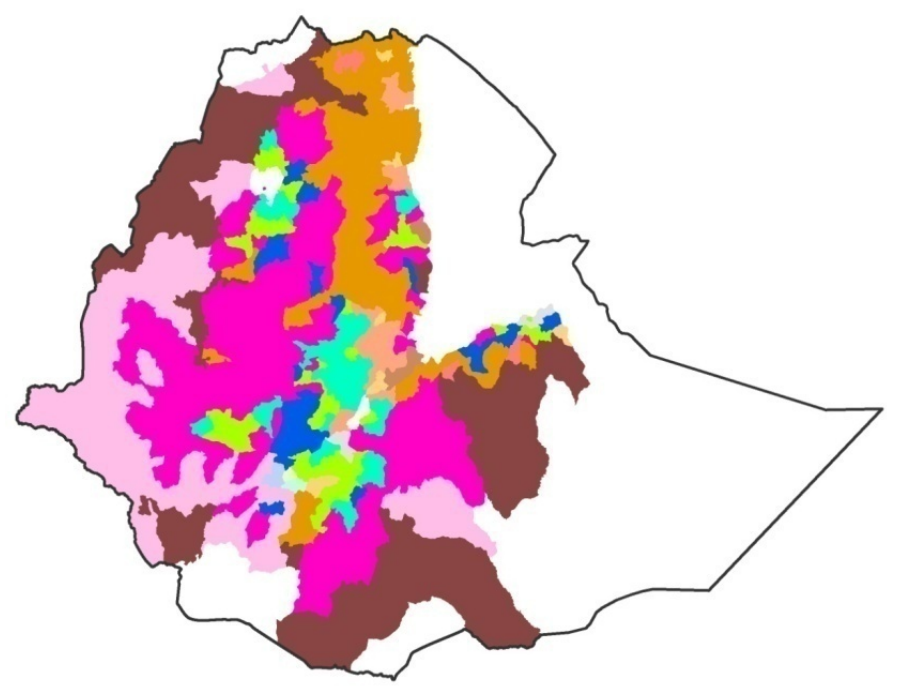

\begin{tabular}{l|ll} 
Drought Prone Highlands, High Access, High Density & Moisture Reliable Highlands, High Access, High Density & Moisture Reliable Lowlands, Low Access, High Density \\
Drought Prone Highlands, High Access, Low Density & Moisture Reliable Highlands, High Access, Low Density & Moisture Reliable Lowlands, Low Access, Low Density \\
Drought Prone Highlands, Low Access, High Density & Moisture Reliable Highlands, Low Access, High Density & Pastoralist, High Access, Low Density \\
\hline Drought Prone Highlands, Low Access, Low Density & Moisture Reliable Highlands, Low Access, Low Density & Pastoralist, Low Access, Low Density \\
\hline Drought Prone Lowlands, High Access, Low Density & Moisture Reliable Lowlands, High Access, High Density & \\
\hline $\begin{array}{l}\text { Drought Prone Lowlands, Low Access, Low Density } \\
\text { Moisture Reliable Lowlands, High Access, Low Density }\end{array}$ &
\end{tabular} 
While crop choice is heavily influenced by biophysical parameters (at least partially captured in the agricultural potential dimension of the domains), access to markets, and land-labor ratios appear to wield considerable influence on production choices and market orientation. Chamberlin et al. (2006) evaluated grain yields (utilizing the Agricultural Census (EASE 2001/02)) with regards to the development domains classifications and found that yields tend to be higher in high access and high density areas (except for oilseeds), although not strongly or uniformly so. In general, the positive impacts of market access and population density on yields likely reflect the greater availability of inputs and labor in these areas and higher returns to using inputs and labor in areas of better access. However, the relatively small differences in grain yields in high- and low-access areas may suggest that factors other than market access are constraining the use of inputs such as fertilizer. A future agricultural census, with disaggregated crop production data, may be able to highlight these issues when evaluated over time, taking into consideration infrastructure improvements and greater access to markets in certain high potential areas of the country.

Cereal commercialization is generally greater in moisture reliable than in drought prone areas, reflecting greater marketable surplus in these higher potential areas. However, in moisture reliable areas, the highest commercialization rates are found in areas of low access, whereas the highest commercialization rates in drought prone areas are in high access areas. In high potential areas, cereals are likely less profitable than higher value commodities such as vegetables in areas of high market access, but may have a strong comparative advantage in areas of low market access. In more drought prone areas, cereals may be the most profitable and/or least risky option for farmers with relatively good market access (but without access to irrigation). Consistent with this explanation, in the drought prone highlands we find the highest commercialization rates for cereals in areas with favorable market access, while in the moisture reliable lowlands we find the lowest commercialization rate for cereals in areas of high access.

These domains were used to structure a set of generalized strategic recommendations. It is not the purpose of these tables to narrowly define recommendations for specific locations, but rather to help link strategic planning within the agricultural sector (and in other sectors) with conditions which could be associated with specific places and through those linkages to enable aggregate strategic planning which corresponds with locally meaningful development priorities. Further definition of those local priorities would most appropriately take place at the local level.

Implicit in these recommendations is a choice of scale, the "resolution" of information and spatial extent. Spatial and informational details are related. For example, recommendations for a particular variety of maize are more detailed than for all varieties together and thus the spatial expression of the optimal conditions will also vary. Generally speaking, maize may have a wide and loosely defined envelope of optimal growing conditions. A given variety, on the other hand, may require soil, slope, temperature, and growing season parameters which are more restricted in space, and which require more detailed data to map. More detailed assessments of this sort, sometimes referred to as technology-specific recommendation domains, may be essential components of addressing specific questions. Nonetheless, the "development domains" approach is fundamentally characterized by its prioritization of economically-relevant conditioning factors which affect multiple production systems. 


\section{Ethiopia's changing economic and biophysical landscape}

The contexts of rural production outlined above have transformed over the last decade given changes in rural infrastructure, expanding urbanization, and the adoption of new technologies. As noted earlier, market access and population density are transforming given expanded transportation and communication networks, as well as greater opportunity to engage in agglomeration economies. Because these transformations mirror, in some respects, the components of the development domains conceptual framework, we follow our empirical assessment of change in development domains from 1994 to 2007 with a brief analysis and discussion of the evolving socio-economic landscape with regards to infrastructure, urbanization, and technology.

\subsection{Infrastructure expansion}

Ethiopia's unique geography continues to play a major role in not only defining suitable areas for specific crop production and development domains, but also the country's economic transformation on the whole. The development of rural areas and agricultural production is characterized by fragmented and dispersed land holdings (average plot size is 0.5 hectares (EASE 2000/01)), limited irrigation potential ${ }^{7}$, and limited infrastructure in peripheral areas of the country.

Related to Ethiopia's biophysical geography is the challenge of building and maintaining infrastructure within a mountainous landscape. Not only improving the physical mobility of people, goods, and services via transportation networks, but also increasing access to telecommunication systems and electrical grids may open opportunities for improved farming and marketing conditions to better realize agricultural potential. The multi-dimensionality of access is important to take into account when viewing change within Ethiopia. For example, information asymmetries are a feature of remoteness and may be mitigated by non-roads investments such as liberalized telecommunications and information markets. We will look at each of these infrastructure types (roads, telecommunications, and electricity) and how improvement over the last several decades has transformed Ethiopia's economy and opened up the potential for significant increases in productivity and output.

\subsection{Improving market access through improved transportation infrastructure}

Given the limited infrastructure during the eighties and early nineties, the Ethiopian government prioritized transportation infrastructure investment in order to enhance linkages between cities in the highlands. In 2007, almost 62 percent of the country's population was within 5 hours travel time from a city of at least 50,000 people (Figure 7.1 and Table 7.1). This shows a major improvement in market access from 1994, when only 33 percent of the total population was within 5 hours travel time from a major city.

7 Highland systems in Ethiopia tend to have smaller catchments and feed from gravelly rivers in the upper part of basins. Flash floods are more common and difficult to predict than are floods in lowland systems. Command areas are relatively small, defined by fluctuating topography. 
Figure 7.1. Travel time 1994 and 2007

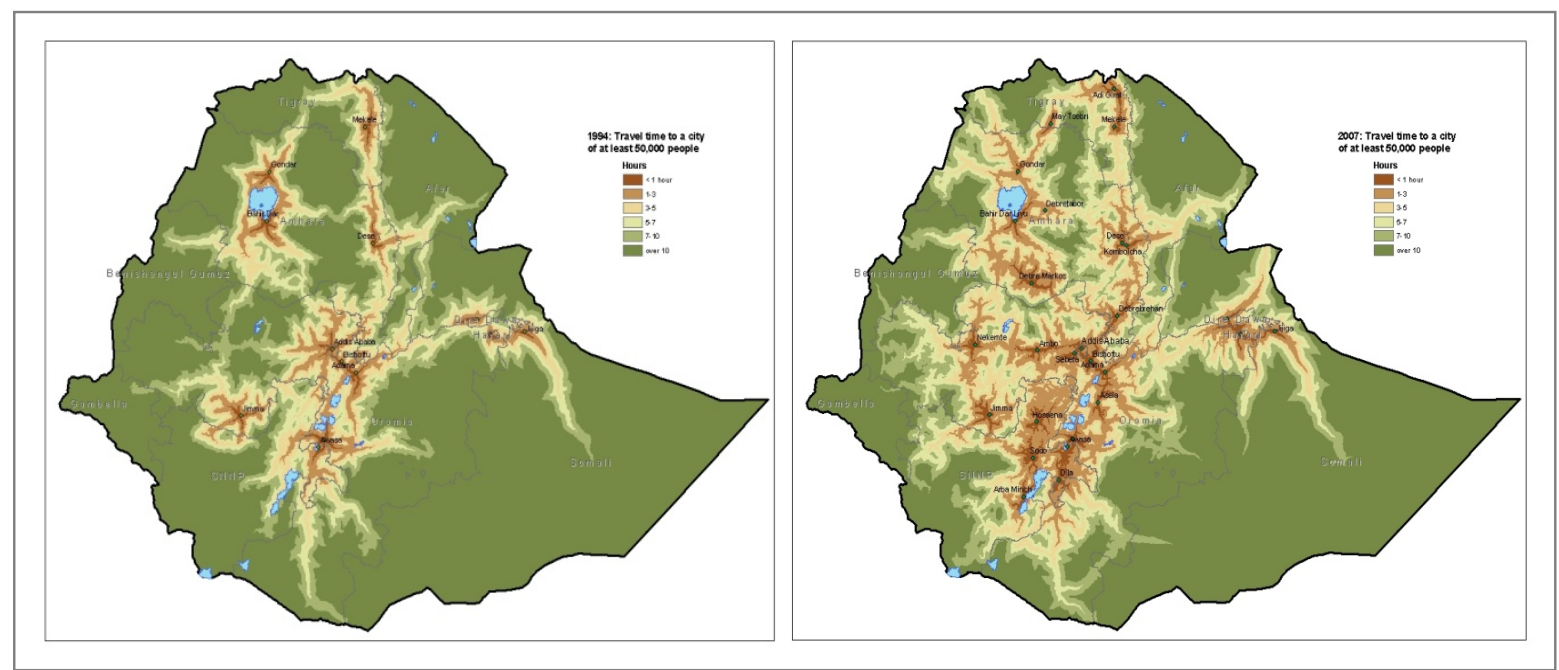

Table 7.1. Percent population connected to a city of at least 50,000 people in 2007

\begin{tabular}{lrrrrr}
\hline Region & Access $<1$ hour & Access $<3$ hours & Access $<5$ hours & Access $<10$ hours & Access $>10$ hours \\
\hline Tigray & 10.89 & 15.36 & 12.48 & 53.71 & 7.57 \\
Afar & - & - & 1.77 & 9.73 & 88.49 \\
Amhara & 5.05 & 22.72 & 37.06 & 31.98 & 3.20 \\
Oromia & 9.03 & 18.06 & 36.39 & 27.84 & 8.68 \\
Somali & 7.99 & - & - & 13.57 & 78.44 \\
Benishangul-Gumuz & - & - & - & 29.15 & 70.85 \\
SNNP & 12.55 & 52.65 & 12.28 & 18.05 & 4.47 \\
Gambella & - & - & - & - & 100 \\
Harar & 100 & - & - & - & - \\
Addis Ababa & 100 & - & - & - & - \\
Dire Dawa & 100 & - & - & 26.03 & - \\
Ethiopia & 12.48 & 23.56 & 25.73 & 12.20 \\
\hline
\end{tabular}

Source: Schmidt and Kedir 2009.

Currently, only 3.2 percent of the population in Amhara and 4.5 percent in SNNPR are more than 10 hours from a major city. SNNPR showed the most improvement in travel time, by connecting 45 percent more people to a city within 3 hours travel time (Table 7.2). In Tigray and Oromia, 21 percent of the population improved market access from more than 10 hours to between 3 and 10 hours from a city. At present, every region except Gambella has a city of at least 50,000 people, and many of these cities have built key transportation infrastructure in order to harness the potential of economic corridors between cities. Although urban centers are linking to other large cities through improved infrastructure, only 5 to13 percent of the population in any region, including the major four regions where primary roads stretch between urban centers, are within one hour travel time to a city of at least 50,000 . 
Table 7.2. Percent change connected to a city of at least 50,000 people from 1994 to 2007

\begin{tabular}{l|rrrrr}
\hline Region & Access $<1$ hour & Access $<3$ hour & Access $<5$ hour & Access $<10$ hour & Access $>10$ hours \\
\hline Tigray & 7.13 & 12.01 & $(3.72)$ & 5.98 & $(21.39)$ \\
Afar & - & - & - & 4.11 & $(5.89)$ \\
Amhara & 2.23 & 14.68 & 18.94 & $(12.49)$ & $(23.35)$ \\
Oromia & 3.74 & 10.40 & 15.84 & $(8.88)$ & $(21.10)$ \\
Somali & - & - & - & 2.62 & $(2.61)$ \\
Benishangul-Gumuz & - & - & - & 17.91 & $(17.91)$ \\
SNNP & 9.17 & 45.37 & $(14.59)$ & $(21.56)$ & $(18.39)$ \\
Gambella & - & - & - & - & - \\
Harari & - & - & - & - & - \\
Addis Ababa & - & - & - & - & - \\
Dire Dawa & - & - & - & - & - \\
Ethiopia & 4.10 & 17.12 & 7.54 & $(9.93)$ & $(18.83)$ \\
\hline
\end{tabular}

Source: Schmidt and Kedir 2009.

Note: Values in parentheses are negative.

It is important to note, however, that population densities and quality/density of transportation infrastructure affect diverse regions in different manners. In Ethiopia, the central and peripheral regions represent two very different economic, geographic, and demographic landscapes. While in the main central regions (Amhara, Oromia, SNNPR, and Tigray), higher population densities and a more integrated road network are characteristic of the economic landscape, in the peripheral regions, limited road access and dispersed settlements create larger challenges for linking remote populations to the benefits of agglomeration economies. Improving transportation infrastructure along main access roads will benefit those already in densely populated areas, but maintaining and building select rural road infrastructure in areas with economic (agricultural) potential will be critical for poverty reduction and economic growth strategies in the more rural, remote areas.

\subsection{Expanding electricity generation}

Large investments in hydro-electric power over the last 30 years have dramatically changed the lives of many individuals living in cities within Ethiopia. In the 1960s, Ethiopia increased its electricity generation capacity from approximately 65 megawatts to an estimated 1,917 (planned) megawatts in 2011, an increase of 8.9 times on a per capita basis (Table 7.3). The comparison with 1958 is even more striking, as there was essentially no electricity generation in Ethiopia at that time, with the nation having only 2.3 megawatts of diesel-powered capacity. The introduction of hydro-electric power in subsequent decades, and especially the large surge in capacity since 2005 raised electricity generating capacity 834-fold between 1958 and 2011, a 29-fold increase on a per capita basis. 
Table 7.3. Electricity generation capacity 1958 to $2011^{*}$ in Ethiopia

\begin{tabular}{l|rrrr}
\hline Year & $\begin{array}{c}\text { Capacity } \\
\text { hydro-electric } \\
\text { (megawatts) }\end{array}$ & $\begin{array}{c}\text { Capacity } \\
\text { other } \\
\text { (megawatts) }\end{array}$ & $\begin{array}{c}\text { Capacity } \\
\text { total } \\
\text { (megawatts) }\end{array}$ & $\begin{array}{c}\text { Capacity per } \\
\text { capita } \\
\text { (watts / person) }\end{array}$ \\
\hline 1959 & - & 2.3 & 2.3 & 0.1 \\
$1960-69$ & 62.8 & 2.5 & 65.4 & 2.4 \\
$1970-79$ & 152.9 & 3.0 & 155.9 & 4.7 \\
$1980-89$ & 202.8 & 4.7 & 207.5 & 4.9 \\
$1990-99$ & 325.2 & 9.0 & 334.2 & 6.0 \\
$2000-04$ & 452.6 & 25.0 & 477.6 & 6.9 \\
$2005-09$ & 747.2 & 50.2 & 797.4 & 10.0 \\
2010 & $1,447.5$ & 50.2 & $1,497.7$ & 17.4 \\
$2011^{*}$ & $1,867.5$ & 50.2 & $1,917.7$ & 21.7 \\
\hline
\end{tabular}

Source: Dorosh and Schmidt 2010

Notes: Figures for 2008-10 based on additional capacity from Tekeze I (300 Mw) in 2009 and Tana Beles (460 Mw) in 2010.

The 2011 figure is the 2010 figure plus Gile Gibe II (420 Mw) for which the tunnel collapsed in December, 2009.

Actual electricity use is generally about 35 to 45 percent of theoretical generating capacity because there is insufficient water behind the hydro-electric power dams for full-scale operation throughout much of the year. Domestic use accounted for 30 percent of total use in 2006/07, while commercial and industrial use accounted for 20 and 28 percent, respectively (Dorosh and Schmidt 2010). Overall, electricity use grew at an average rate of 12.5 percent per year from 2002/03 to 2006/07, with the highest growth rate for street lighting (27.1 percent per year).

Recent research on the productivity effects of electrification suggests that benefits from improved and extended hours of access could be very large, particularly, as measured by output per worker. A 2008 survey of small-scale handlooms in Addis Ababa and SNNPR (Ayele et al. 2009) indicates that productivity per worker is about 40 percent higher for electrified versus non-electrified firms in SNNPR. Workers in non-electrified rural villages on average worked only 7.2 hours per day, whereas their counterparts in other electrified (but rural) villages worked 10.7 hours per day. This productivity effect is achieved in large part because in towns with electricity access, producers work longer hours and firms share workspaces with electric lights at lower rental cost.

\subsection{Enhancing telecommunications}

Ethiopia is gradually becoming connected. Individuals that once had to walk hours to gain information about market prices and supply are steadily joining a network of connected individuals that are able to let their fingers do the walking. In 2003, 405,000 fixed telephone lines were in place and only 50,000 cell phone subscriptions existed throughout the country (Table 7.4 and Figure 7.5). By 2008, cell phone subscription catapulted to 3.16 million subscribers and fixed telephone lines more than doubled. Infrastructure plans report that cell phone subscriptions will more than double by 2009 and will reach as many as 9.9 million users by 2010. It is important to note, however, that only 3.9 percent of the total population has a cell phone subscription (5.3 percent of subscribers are located in connected areas), whereas the share of population with cellular subscriptions within a connected area in SubSaharan Africa reaches 32.5 percent of the population. Total cell phone subscribers 
in Africa amount to 245.6 million people, while a total of approximately 3.16 million Ethiopians benefit from a cellular subscription.

Table 7.4. Fixed line and cellular telephones 2003 to 2010 in Ethiopia

\begin{tabular}{lrrrr}
\hline & 2003 & 2008 & $2009^{*}$ & $2010^{*}$ \\
\hline Main (fixed) telephone lines ('000) & & & & \\
$\quad$ Ethiopia & 405 & 909 & 3,000 & 4,400 \\
Africa & 9,553 & 10,617 & - & - \\
Mobile cellular subscriptions ('000) & & & & \\
Ethiopia & 51 & 3,168 & 7,500 & 9,900 \\
Africa & 35,251 & 245,608 & - & - \\
Mobile cellular subscriptions (per 100 people) & & & & \\
Ethiopia (share of total population) & 0.1 & 3.9 & 9 & 11.5 \\
Ethiopia (share in connected area) & 0.1 & 5.3 & - & - \\
Africa (share in connected area) & 3.7 & 32.5 & - & - \\
\hline
\end{tabular}

Source: Dorosh and Schmidt 2010

Note: * Planned coverage

Figure 7.2. Fixed line and cellular telephones 2003 to 2010 in Ethiopia

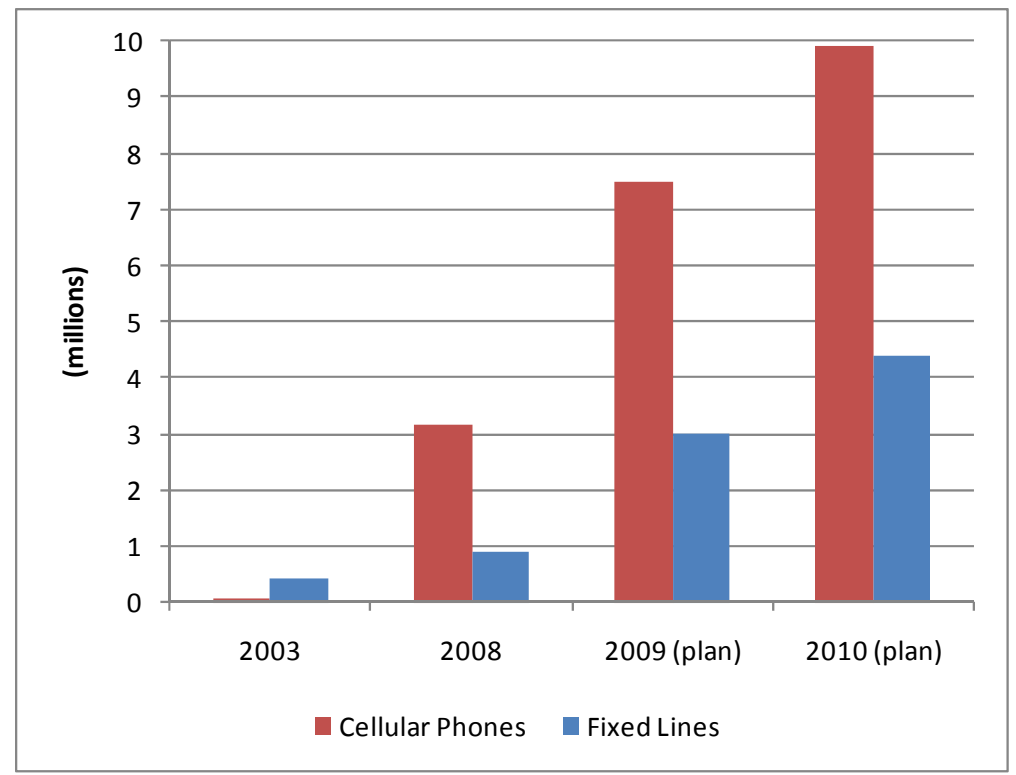

Sources: ITU 2009. Information Society Statistical Profiles 2009 - Africa, International Telecommunication Union (ITU).; Ethiopian Telecommunications Corporation (ETC). ETC Strategic Plan.

http://www.ethionet.et/aboutus/visionmission.html 


\section{Urban growth and expansion}

The recent publication of Ethiopia's 2007 census reports urban population figures at the city level and allows for greater insight into how Ethiopia's demographic landscape has evolved. Schmidt and Kedir (2009) provide an analysis of city growth and expansion using city population, infrastructure networks, and population density in order to provide a standardized comparison of urban growth over the last 3 census periods (Table 8.1).

Table 8.1. Agglomeration index ${ }^{*}$ - Percent of people considered urban by region

\begin{tabular}{|c|c|c|c|c|c|c|}
\hline & \multicolumn{2}{|c|}{$1984^{* *}$} & \multicolumn{2}{|c|}{1994} & \multicolumn{2}{|c|}{2007} \\
\hline Regions & $\begin{array}{l}\text { Total } \\
\text { Population } \\
\text { (thousands) }\end{array}$ & $\begin{array}{l}\text { Percentage } \\
\text { Urban }\end{array}$ & $\begin{array}{l}\text { Total } \\
\text { Population } \\
\text { (thousands) }\end{array}$ & $\begin{array}{l}\text { Percentage } \\
\text { Urban }\end{array}$ & $\begin{array}{l}\text { Total } \\
\text { Population } \\
\text { (thousands) }\end{array}$ & $\begin{array}{l}\text { Percentage } \\
\text { Urban }\end{array}$ \\
\hline Addis Ababa & 1,423 & 61.2 & 2,113 & 85.5 & 2,738 & 99.3 \\
\hline Afar & 780 & - & 1,061 & - & 1,411 & - \\
\hline Amhara & 10,686 & 2.0 & 13,834 & 3.7 & 17,214 & 7.5 \\
\hline Benishangul-Gumuz & 351 & - & 460 & - & 671 & - \\
\hline Dire Dawa & 158 & 20.3 & 252 & 58.2 & 343 & 66.3 \\
\hline Gambella & 172 & -1 & 182 & - & 307 & - \\
\hline Harari & 82 & 55.2 & 131 & 76.2 & 183 & 86.0 \\
\hline Oromia & 14,016 & 1.7 & 18,733 & 4.6 & 27,158 & 9.2 \\
\hline SNNPR & 7,501 & - & 10,377 & 2.2 & 15,043 & 21.1 \\
\hline Somali & 2,006 & 0.2 & 3,199 & 1.6 & 4,439 & 1.9 \\
\hline Tigray & 2,692 & 2.0 & 3,136 & 3.8 & 4,314 & 8.0 \\
\hline Ethiopia & 39,869 & 3.7 & 53,477 & 7.1 & 73,919 & 14.2 \\
\hline
\end{tabular}

Source: Schmidt and Kedir 2009

Notes: * Population density per square kilometer (derived by GRUMP and LandScan for the year 2000), a major component in the agglomeration index, was projected using a growth rate of $3 \%$ per annum to adjust for different census years.

**Population figures for 1984 were approximated due to changes in administrative boundaries after 1984. In order to maintain consistency across all years, we geographically allocated population to the current regional boundaries.

Urban estimates from the 2007 census are similar to those estimated by Schmidt and Kedir (2009) for 2007 using the agglomeration index methodology, yet when comparing urban growth over time, these estimates show a dramatic difference (Table 8.2). This difference is primarily derived from the definition of an urban area used for the two estimates. The Central Statistical Agency measures urban areas as all administrative capitals of regions, zones, and woredas, as well as localities with at least 1,000 people who are primarily engaged in non-agricultural activities, and/or areas where the administrative official declares the locality to be urban. In comparison, the agglomeration index provides a measure of the economic significance of urban areas rather than a definition of urban based on political status, administrative boundary, or presence of particular urban services or activities. 
Table 8.2. Ethiopia: Alternative urbanization estimates

\begin{tabular}{|c|c|c|}
\hline & $\begin{array}{r}\text { Official Estimate } \\
\text { (percent) }\end{array}$ & $\begin{array}{r}\text { Agglomeration Index } \\
\text { (percent) }\end{array}$ \\
\hline 1984 & $11.40 \%$ & $3.70 \%$ \\
\hline 1994 & $13.70 \%$ & $7.10 \%$ \\
\hline \multirow[t]{2}{*}{2007} & $15.90 \%$ & $14.20 \%$ \\
\hline & (mns people) & (mns people) \\
\hline 1984 & 4.55 & 1.48 \\
\hline 1994 & 7.33 & 3.8 \\
\hline \multirow[t]{2}{*}{2007} & 11.72 & 10.5 \\
\hline & (growth rate) & (growth rate) \\
\hline 1984-1994 & $4.90 \%$ & $9.90 \%$ \\
\hline $1994-2007$ & $3.70 \%$ & $8.10 \%$ \\
\hline $1984-2007$ & $4.20 \%$ & $8.90 \%$ \\
\hline
\end{tabular}

Source: CSA population estimates; Schmidt and Kedir 2009.

Evaluating Ethiopia's urban growth using the agglomeration index methodology shows that urbanization growth rates are much higher (approximately nine percent on average) than previously calculated by the CSA (on average four percent over the last three decades). Although Ethiopia's agglomeration index suggests significant levels of urban clustering and growth over time, when comparing with other countries in the region, Ethiopia remains one of the least urbanized in East Africa. In 2000, agglomeration in Ethiopia was measured at 11.9 percent, while most other East African countries were between 25 and 32 percent. Overall, Ethiopia's agglomeration index is 10 percentage points below the average agglomeration index for East Africa.

Given the overwhelming revenue generated from agricultural activities in Ethiopia, policymakers have focused primarily on Agricultural Development Led Industrialization (ADLI), but continuous growth of urban centers requires a greater understanding of the dynamic geographic and economic transformations occurring throughout the country. Urban areas facilitate social and economic interactions. These exchanges lead to increased efficiency in flows of goods and services, more efficient matching of workers to jobs, and enhanced information and knowledge spillovers. Increased access to markets also affects development domains, allowing for improved access to new technologies, necessary inputs to boost production and yields, and increased opportunity for cash-crop development for export. Earlier evidence by Chamberlin et al. (2006) suggests that grain yields tend to be higher in high access and high density areas, suggesting that a network of well-connected primary and secondary cities facilitates access to agricultural inputs, as well as creates the necessary demand for sustainable increases in production and yields. 


\section{New technologies}

Technologies developed for enhanced agricultural production can either take advantage of inherent biophysical conditions or redefine these conditions by way of reducing previous environmental constraints (such as irrigation development in rainfed areas with drought prone conditions). Since 1991, the Government of Ethiopia has sought to enhance food staple production through the use of modern inputs, such as seed and fertilizer packages, irrigation schemes, and agricultural extension (FDRE 2006a, 2002).

\subsection{Improved seed}

The programs and investments set forth by the GoE and other donor agencies suggest that while the total quantity of improved seed supplied nationally has been increasing since 1996-97, farmer use of improved seed covered an average of only 4.7 percent of cropped area in 2007-08. A large determinant of farmer utilization of improved seed may depend on the type of crop being produced. For example, Lantican et al. (2005) reported that in 2002, 71 percent of all wheat area in the country was sown with improved varieties, although only 43 percent of the area under improved wheat varieties was sown with varieties released since 1995 (implying long-term seed recycling). In contrast, CSA reported in 2008 that only 20 percent of area under maize production utilizes improved varieties and hybrids, whereas teff, barley, and sorghum adoption rates of improved varieties are relatively lower than both wheat and maize.

\subsection{Fertilizer}

Chemical fertilizer application continues to represent a challenge due to the cost incurred by farmers with small landholdings and limited cash resources that necessitate small purchases of fertilizer that are more costly for retailers to sell (Harrigan 2008; Jayne et al. 2003). In addition, lack of irrigation and highly fluctuating rainfall patterns contribute to high variability in fertilizer success, and in turn unpredictable demand for fertilizer. Research by Yu et al. (2010) finds that production specialization, together with wealth play a major role in explaining crop area under fertilizer and improved seed. Another important factor behind limited adoption of technological packages (improved seed and fertilizer) and inefficiency of input use is lack of appropriate, timely, and quality extension services (including distribution and development assistance) to promote more efficient use of inputs and to accommodate risks associated with agricultural production, especially among small and poor households.

\subsection{Spatial variations in technology use}

As development domains and crop types are defined by specific biophysical conditions, there are also substantial variations in the adoption of improved technology due to underlying characteristics. When analyzing the Agricultural Sample Survey (2003/04-2008/09), Yu et al. found that areas such as West Gojam (Amhara region) and Jimma (Oromia region) achieved relatively high technology adoption rates in maize, while adoption was low for other crops. Similarly, most of the area under fertilizer is concentrated in Amhara and Oromia, regions that comprise the necessary biophysical characteristics for production along with a well-linked transportation network. These areas include South Gonder, Awi, and West and East 
Gojam in Amhara Region and East Wellega, Jimma, West Shewa, Arsi, and East Shewa in Oromia Region stretching into Sidama Region in SNNP. In general, these areas share common precursors to success. They all benefit from high suitability for crop production and a well-placed infrastructure network that eases access to markets.

The spatial distribution of the area under fertilizer and improved seed varies by crop. Maize and wheat are the main crops that receive the fertilizer and/or improved seed (Table 9.1). In 2006, approximately 22 percent of maize crop area was under the improved seed and fertilizer package and 16 percent of the area used fertilizer with local seed. Roughly 54 percent of area planted with wheat uses fertilizer and another two percent uses the fertilizer and improved seed package.

Table 9.1. Area, production and yields of cereals using modern inputs or traditional technology

\begin{tabular}{|c|c|c|c|c|c|c|c|c|}
\hline \multirow[t]{2}{*}{ Crop and technology } & \multicolumn{4}{|c|}{ Total area (000 hectare) } & \multicolumn{4}{|c|}{ Share in crop area (\%) } \\
\hline & 2003 & 2004 & 2005 & 2006 & 2003 & 2004 & 2005 & 2006 \\
\hline \multicolumn{9}{|l|}{ Barley } \\
\hline Fertilizer \& improved seed & 0.8 & 1.8 & 0.9 & 1.2 & 0.1 & 0.3 & 0.1 & 0.2 \\
\hline Fertilizer \& local seed & 145.6 & 164.4 & 173.0 & 140.6 & 25.8 & 25.6 & 27.3 & 26.6 \\
\hline No fertilizer \& improved seed & 1.2 & 2.1 & 0.1 & 0.2 & 0.2 & 0.3 & 0.0 & 0.0 \\
\hline No fertilizer \& local seed & 415.6 & 474.2 & 459.0 & 386.8 & 73.8 & 73.8 & 72.5 & 73.1 \\
\hline Total & 563.1 & 642.5 & 632.9 & 528.9 & 100.0 & 100.0 & 100.0 & 100.0 \\
\hline \multicolumn{9}{|l|}{$\underline{\text { Maize }}$} \\
\hline Fertilizer \& improved seed & 197.2 & 158.1 & 188.9 & 192.2 & 23.4 & 17.7 & 17.7 & 21.6 \\
\hline Fertilizer \& local seed & 99.5 & 124.6 & 211.2 & 146.3 & 11.8 & 13.9 & 19.7 & 16.4 \\
\hline No fertilizer \& improved seed & 10.7 & 9.5 & 9.9 & 5.0 & 1.3 & 1.1 & 0.9 & 0.6 \\
\hline No fertilizer \& local seed & 536.1 & 601.6 & 660.1 & 547.9 & 63.6 & 67.3 & 61.7 & 61.5 \\
\hline Total & 843.5 & 893.8 & 1070.2 & 891.3 & 100.0 & 100.0 & 100.0 & 100.0 \\
\hline \multicolumn{9}{|l|}{$\underline{\text { Teff }}$} \\
\hline Fertilizer \& improved seed & 3.7 & 7.7 & 8.2 & 9.7 & 0.3 & 0.5 & 0.5 & 0.6 \\
\hline Fertilizer \& local seed & 634.2 & 705.0 & 902.2 & 821.4 & 45.2 & 47.2 & 54.4 & 53.5 \\
\hline No fertilizer \& improved seed & 4.7 & 3.7 & 2.1 & 2.2 & 0.3 & 0.2 & 0.1 & 0.1 \\
\hline No fertilizer \& local seed & 761.4 & 778.7 & 745.8 & 701.7 & 54.2 & 52.1 & 45.0 & 45.7 \\
\hline Total & 1404.0 & 1495.0 & 1658.3 & 1535.0 & 100.0 & 100.0 & 100.0 & 100.0 \\
\hline \multicolumn{9}{|l|}{ Wheat } \\
\hline Fertilizer \& improved seed & 24.9 & 28.3 & 22.5 & 14.1 & 3.7 & 3.4 & 2.6 & 2.0 \\
\hline Fertilizer \& local seed & 341.6 & 418.7 & 533.0 & 379.9 & 50.1 & 50.4 & 60.6 & 53.8 \\
\hline No fertilizer \& improved seed & 5.8 & 5.3 & 4.2 & 6.1 & 0.9 & 0.6 & 0.5 & 0.9 \\
\hline No fertilizer \& local seed & 308.9 & 379.0 & 320.3 & 305.5 & 45.4 & 45.6 & 36.4 & 43.3 \\
\hline Total & 681.2 & 831.3 & 880.0 & 705.7 & 100.0 & 100.0 & 100.0 & 100.0 \\
\hline
\end{tabular}

Source: Yu, et al. 2010.

Previous studies on technology adoption find clear spatial patterns suggesting that biophysical characteristics and access to main roads and market centers determine success and pace of adoption (Croppenstedt 2003; Staal et al. 2002; Yu et al. 2010). Ethiopia's varying agroecological zones, variable rainfall, and topographic heterogeneity hinders technological diffusion across large areas. This unique landscape also provides challenges in providing nuanced recommendations for specific biophysical features. In addition, farmers in remote areas with limited access to inputs and relatively thin markets for agricultural produce may incur significant transport costs, with decreased benefits. Further investment in connective infrastructure that reduces distance to areas of greater density and enhances access to information and markets is likely to accelerate adoption. 


\section{Conclusions}

The underlying biophysical features and unique topographic environment of Ethiopia strongly influence, but may not strictly delineate the success of agricultural production and output within the country. Although natural endowments are significantly linked to agricultural suitability, the changing economic landscape is beginning to blur the boundaries between the 'actual' suitable areas and the 'potentially' productive locations. Access to input and output markets, expanding urbanization, and improved technologies are transforming the landscape, as well as the activities and opportunities within previously limiting agroecological zones. Understanding the geographical expression of these factors is an important way of making sense of Ethiopia's agricultural and rural development options and for guiding the definition of supporting policies.

Investments in connective infrastructure are facilitating the movement of ideas, technologies, goods and services, and labor to areas that demand specific products and distribute other outputs. Improving and restoring primary road infrastructure reinforces secondary and primary market interactions. Maintaining and constructing rural roads that connect agricultural surplus areas with small towns and urban centers also bolster inclusive geographic supply and demand networks. A continuum of population density creates a portfolio of interrelated places and these places, when functioning properly, will bring about greater economic interaction and ultimately spur development within all spatial spheres.

Clearly, the transformations that have taken place in the last decades with regards to market access, technology investment, and urbanization have facilitated and influenced not only city development and productivity, but rural economic growth and potential as well. This growth requires policy decisions which shape the rate of growth and integration between rural and urban areas, as well as a framework for how Ethiopia can best benefit from enhancing the already (actual) agriculturally productive areas, while bolstering areas that have significant potential for greater output. 


\section{References}

Ayele, G., J. Chamberlin, L. Moorman, K. Wamisho, and X. Zhang. 2009. Infrastructure and Cluster Development: A Case Study of Handloom Weavers in Ethiopia. ESSP-II Discussion Paper 1. Addis Ababa: International Food Policy Research Institute.

Binswanger, H. P., and J. McIntire. 1987. Behavioral and material determinants of production relations in land abundant tropical agriculture. Economic Development and Culture Change 35 (1): 73-99.

Boserup, E. 1965. The Conditions of Agricultural Growth. New York: Aldine.

Brandt, S. A., A. Spring, C. Hiebsch, J.T. McCabe, E. Tabogie, M. Diro, G. WoldeMichael, G. Yntiso, M. Shigeta, and S. Tesfaye. 1997. The Tree against Hunger. American Association for the Advancement of Science. Washington, DC.

Chamberlin, J., J. Pender, and B. Yu. 2006. Development domains for Ethiopia: Capturing the geographical context of smallholder development options. DSGD Discussion Paper 43. Washington, D.C.: International Food Policy Research Institute.

Chomitz, K.M., and D.A. Gray. 1996. Roads, land use, and deforestation: a spatial model applied to Belize. World Bank Economic Review 10 (3): 487-512.

Croppenstedt, A., M. Demeke, and M. Meschi. 2003. Technology adoption in the presence of constraints: The case of fertilizer demand in Ethiopia. Review of Development Economics 7 (1): 58-70.

CSA, IFPRI \& EDRI. 2006. Atlas of the Ethiopian Rural Economy. Central Statistics Authority (CSA), International Food Policy Research Institute (IFPRI), and the Ethiopian Development Research Institute (EDRI), Addis Ababa.

De Pauw, E., and H.Y. Bruggeman. 1988. A Summary of the Agricultural Ecology of Ethiopia. Rome: Food and Agricultural Organization.

Dorosh, P., and E. Schmidt. 2010. The Rural Urban Transformation in Ethiopia. IFPRI - Ethiopia Strategy Support Program (ESSPII) Discussion Paper 13. Washington, D.C.: International Food Policy Research Institute.

EASE. Ethiopian Agricultural Sample Enumeration. Assessment of Crop Conditions. 2001/02 (1994 E.C.). Addis Abeba: Central Statistical Agency of Ethiopia.

FAO/EMA. 1983. Generalized Agro Climatic Map of Ethiopia. Rome: Food and Agricultural Organization and Addis Ababa: Ethiopian Mapping Agency.

FAO. 1978. Report on the Agroecological Zones Project. World Soil Resources Report 48 (1). Rome: Food and Agricultural Organization.

The Federal Democratic Republic of Ethiopia Ministry of Works and Urban Development: Ethiopian Roads Authority 200. RSDP Performance: Eleven Years Later.

FDRE Population Census Commission. December 2008. Summary and Statistical Report of the 2007 - Population Size by Age and Sex. Federal Democratic Republic of Ethiopia (FDRE).

FDRE (Federal Democratic Republic of Ethiopia). 2006. Ethiopia: Building on Progress: A Plan for Accelerated and Sustained Development to End Poverty. Addis Ababa: Ministry of Finance and Economic Development (FDRE). 
FDRE (Federal Democratic Republic of Ethiopia). 2002. Ethiopia: Sustainable Development and Poverty Reduction Program. Addis Ababa: Ministry of Finance and Economic Development (FDRE).

Harrigan, J. 2008. Food insecurity, poverty, and the Malawian Starter Pack: Fresh start or false start? Food Policy 33: 237-249.

Hurni, H. 1998. Agroecological Belts of Ethiopia: Explanatory notes on three maps at a scale of 1:1,000,000. Research Report, Soil Conservation Research Program, Addis Ababa.

Jayne, T.S., J. Govereh, M. Wanzala, and M. Demeke. 2003. Fertilizer market development: A comparative analysis of Ethiopia, Kenya, and Zambia. Food Policy 28: 293-316.

Lantican, M.A., H.J. Dubin, and M.L. Morris. 2005. Impacts of International Wheat Breeding Research in the Developing World, 1988-2002. Mexico, D.F.: CIMMYT.

McIntire, J., D. Bourzat, and P. Pingali. 1992. Crop-Livestock Interaction in SubSaharan Africa. Washington, D.C.: World Bank.

National Research Council. 1996. Lost Crops of Africa, In Grains, volume 1, ed.Vietmeyer, N.D. Washington, D.C.: National Research Council, National Academy Press.

Nkonya, P., J. Pender, P. Jagger, D. Sserunkuuma, C.K. Kaizzi, and H. Ssali. 2004. Strategies for sustainable land management and poverty reduction in Uganda. Research Report 133. Washington, D.C.: International Food Policy Research Institute.

Openshaw, S. 1984. The Modifiable Areal Unit Problem: Concepts and Techniques in Modern Geography. Norwich: Geo Books.

Pender, J. 2001. Rural population growth, agricultural change and natural resource management in developing countries: A review of hypotheses and some evidence from Honduras. In Population Matters: Demographic Change, Poverty and Economic Growth in Developing Countries, ed. N. Birdsall, S. Sinding, and A. Kelley. Oxford: Oxford University Press.

2004a. Development pathways for hillsides and highlands: some lessons from Central America and East Africa. Food Policy 29: 339-367.

2004b. Targeting rural investments in the highlands of northern Ethiopia. Paper prepared for USAID/Ethiopia. Environment and Production Technology Division. Washington, D.C.: International Food Policy Research Institute, Mimeo.

Pender, J., S. Ehui, and F. Place. 2006. Conceptual framework and hypotheses. In Strategies for Sustainable Land Management in the East African Highlands. ed. J. Pender, F. Place, and S. Ehui. Washington, D.C.: International Food Policy Research Institute.

Pender, J., F. Place, and S. Ehui. 1999. Strategies for sustainable agricultural development in the East African Highlands. In Strategies for Poverty Alleviation and Sustainable Resource Management in the Fragile Lands of Sub-Saharan Africa. ed. A. Knox McCullough, S. Babu, and P. Hazell. Proceedings of the International Conference, May 25-29, 1998, in Entebbe, Uganda. Feldafing, Germany: Food and Agriculture Development Centre (DSE/ZEL). 
Pender, J., F. Place, and S. Ehui. 2006. Strategies for sustainable land management in the East African highlands: conclusions and implications. In: Strategies for Sustainable Land Management in the East African Highlands, ed. Pender, J., Place, F., and S. Ehui. Washington, D.C.: International Food Policy Research Institute.

Pender, J., B. Gebremedhin, S. Benin, and S. Ehui. 2001a. Strategies for sustainable development in the Ethiopian highlands. American Journal of Agricultural Economics 83 (5):1231-1240.

Pender, J., P. Jagger, E. Nkonya, and D. Sserunkuuma. 2001b. Development pathways and land management in Uganda: Causes and implications. Environment and Production Technology Division Discussion Paper 85. Washignton, D.C.: International Food Policy Research Institute.

Pender, J., P. Jagger, E. Nkonya and D. Sserunkuuma. 2004. Development pathways and land management in Uganda. World Development 32 (5): $767-$ 792.

Pingali, P.,Y. Bigot, and H. P. Binswanger. 1987. Agricultural mechanization and the evolution of farming systems in sub-Saharan Africa. Baltimore: Johns Hopkins University Press.

Ruthenberg, H. 1980. Farming systems in the tropics. Oxford: Clarendon Press.

Schmidt, E., and M. Kedir. 2009. Urbanization and Spatial Connectivity in Ethiopia: Urban Growth Analysis using GIS. IFPRI - ESSP II Discussion Paper 3. Washington, D.C.: International Food Policy Research Institute.

Staal, S.J., I. Baltenweck, M. M. Waithaka, T. de Wolff, and L. Njoroge. 2002. Location and uptake: Integrated household and GIS analysis of technology adoption and land use, with application to smallholder dairy farms in Kenya. Agricultural Economics 27: 295-315.

Tadesse, M., B. Alemu, G, Bekele, T. Tebikew, J. Chamberlin, and T. Benson. 2006. Atlas of the Ethiopian Rural Economy. Addis Ababa, Ethiopia: Ethiopian Development Research Institute.

von Thünen, J. 1826. The Isolated State. English edition, London: Pergamon.

Westphal, E. 1975. Agricultural Systems in Ethiopia. Agricultural Research Reports 826, Wageningen.

Wood, S., K. Sebastian, F. Nachtergaele, D. Nielsen, and A. Dai. 1999. Spatial aspects of the design and targeting of agricultural development strategies. Environment and Production Technology Division Discussion Paper 44. Washington, D.C.: International Food Policy Research Institute.

Yu, Bingxin, A. Nin-Pratt, J. Funes, and S. Asrat. 2010. Cereal Production and Technology in Ethiopia. IFPRI - ESSP II Discussion Paper 12. Washington, D.C.: International Food Policy Research Institute. 
INTERNATIONAL FOOD POLICY RESEARCH INSTITUTE 2033 K Street, NW | Washington, DC 20006-1002 USA $\mathrm{T}:+1.202 .862 .5600$ | F: +1.202.457.4439

Skype: ifprihomeoffice | ifpri@cgiar.org | www.ifpri.org

\section{IFPRI-ESSP ADDIS ABABA}

P.O. Box 5689, Addis Ababa, Ethiopia

$\mathrm{T}:+251.11 .617 .2000$ | F: +251.11.646.2318

mahlet.mekuria@cgiar.org | http://essp.ifpri.info
ETHIOPIAN DEVELOPMENT RESEARCH INSTITUTE

P.O. Box 2479, Addis Ababa, Ethiopia

$\mathrm{T}:$ +251.11.550.6066; +251.11.553.8633 | F: +251.11.550.5588

info@edri-eth.org | www.edri-eth.org

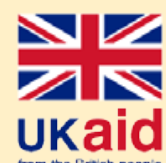

The Ethiopia Strategy Support Program (ESSP) is financially supported by the United States Agency for International Development (USAID) and UK aid from the United

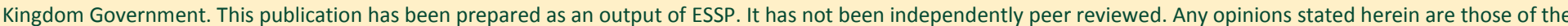

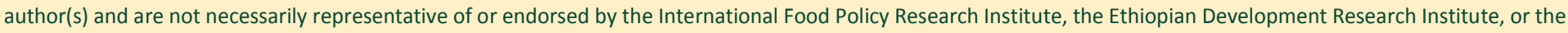
donors.

Copyright (c) 2011 International Food Policy Research Institute. All rights reserved. To obtain permission to republish, contact ifpri-copyright@cgiar.org. 